
професор кафедри філологічних дисциплін та методики їх викладання Чернігівського обласного інституту післядипломної педагогічної освіти імені К. Д. Ушинського

\title{
КАТАСТРОФІЗМ ХУДОЖНЬОГО ПРОСТОРУ ОПОВІДАННЯ Р. СЕЙСЕНБАЄВА «ДЕНЬ, КОЛИ ОБВАЛИВСЯ СВІТ»
}

У статті на прикладі оповідання Роллана Сейсенбаєва «День, коли обвалився світ» розглянуто катастрофізм як літературне ідейно-стильове явище. Системно і комплексно проаналізовано тендениії та засоби мистецького втілення катастрофізму, передусім, його технократичної модифікачії. Розкрито семантико-структурні трансформації, екзистенційні модуси й авторські інтенції, каталізатором яких став катастрофізм. Вказано на типологічну спорідненість форм художнього зображення в оповіданні Р. Сейсенбаєва «День, коли обвалився світ» та творах чорнобильської тематики.

Ключові слова: дискурс катастрофізму, технократична модель катастрофізму, документалістика, есхатологізм,екзистенціалізм, типологічні збіги.

В статье на примере рассказа Роллана Сейсенбаева «День, когда рухнул мир» рассмотрено катастрофизм как литературное идейно-стилистическое явление. Системно и комплексно проанализировань тенденщии и средства художественного воплощения катастрофизма, прежде всего его технократической модификации. Раскрыто семантикоструктурные трансформации, экзистенциональные модусы и авторские интенции, катализатором которых стал катастрофизм. Установлено типологическое сходство художественньх приёмов воплощения катастрофизма в рассказе Р. Сейсенбаева «День, когда рухнул мир» и в произведениях чернобыльской тематики. 
Ключевые слова: дискурс катастрофизма, технократическая модель катастрофизма, документалистика, эсхатологизм, экзистенциализм, типологические соответствия.

On the base of the story by Rollan Seysenbayev "The Day, when the World has collapsed» the author analyzes catastrophism as the ideological and stylistic literary phenomenon. The author systematically and comprehensively analyzes the trends and means of artistic embodiment of catastrophism, primarily its technocratic modification. The article reveals the catastrophism as the catalyst of semantic and structural transformation, existential modes and author intentions. The author emphasizes the typological affinity of artistic images of $R$. Seysenbayev's story "The Day, when the World has collapsed» and the works of Chernobyl theme.

Key words: catastrophism discourse, technocratic model of catastrophism, documentation, eschatology, existentialism, typological coincidences.

Катастрофічні тенденції у вітчизняному літературознавстві вивчалися на різних рівнях та у різних філософсько-естетичних моделях. Їх українська дослідниця О. Харлан виокремлює три: історіософську, антропологічну та технократичну [Харлан 2008:8].

Філософські підвалини дискурсу катастрофізму розробляли О. Шпенглер, М. Бердяєв, Г. Зіммель, Й. Гейзинга. Останній, зокрема, вказував на неоднозначний характер технічного прогресу в праці «У затінку завтрашньої днини»: «Сподівання, щзо кожне нове відкриття чи вдосконалення неодмінно втілять обічянку чогось вартіснішого або ж більшого щуастя - досить наӥвна річ, спадок чаруючої пори інтелектуального, морального і сентиментального оптимізму ХVIII століття. Немає нічого парадоксального у вислові, щзо в прочесі досить суттєвого $i$ безперечного прогресу та чи та культура може знайти свою погибель. Прогрес - ризикована справа $і$ неоднозначне поняття» [Гейзинга: Електронний ресурс]. Гуманістичний чинник під час розгляду антиномії цивілізація/культура виразно простежується і в працях Х. Ортеги-і-Гассета, М. Гайдеггера. В українській культурі ці ідеї у згорнутому вигляді існували, зокрема, вже у хутірській філософії П. Куліша [Дзюба 1998:46], яка випередила європейську думку в напрямі пошуків відповідності між розвитком культури і цивілізації. Члени Римського клубу, котрі поставили собі за мету осмислити становище людства в епоху науковотехнічної революції, вважали глобальними деякі з тих проблем, які ескізно були 
окреслені П. Кулішем, насамперед про наслідки цивілізації - найближчі та віддалені.

У своєму дослідженні ми маємо наміри розкрити техногенний варіант катастрофізму, - його аспект, пов’язаний з ядерними інцидентами. Щоправда, складністю $є$ досить широке тлумачення поняття «катастрофізм», навіть у межах однієї моделі. Для створення цілісної характеристики катастрофічних тенденцій скористаємося порівняльно-типологічним, історико-функціональним, культурно-історичним, філологічним методами, прийомами герменевтики.

В українській літературно-критичній та літературно-теоретичній сферах означений дискурс репрезентований, передусім, рефлексіями над творами чорнобильської тематики. Предметом аналізу у різний час ставали роман В. Яворівського «Марія 3 полином у кінці століття», документальна повість Ю. Щербака «Чорнобиль», поезія Д. Павличка «Листок», поеми: Б. Олійника «Сім», М. Луківа «Біль і пам’ять», М. Сингаївського «Обпалена мужність», Л. Горлача «Зона», С. Йовенко «Вибух», І. Драча «Чорнобильська мадонна» та ін.

У компаративних студіях значна увага приділена роману-свідченню С. Алексієвич «Чорнобильська молитва: хроніка майбутнього». На осібне місце Чорнобиля 3-поміж об'єктів катастрофічного дискурсу вказує один із героїв роману: «Чорнобиль відкрив безодню, щ⿻ось таке, щзо поза Колимою, Освенциимом i Голокостом» [Алексієвич 1998:136]. Відповідно з'явилася потреба: у пошуках нової образно-художньої мови, яка мала прийти на зміну безгомінню - першій реакції на трагедію; у нових формах зображення катастрофічного дискурсу; у трансформації жанрової системи (вона зазнала видозмін, передусім, під впливом тяжіння авторів до автобіографізму та документалістики). Адже, за спостереженням Л. Гінзбург, документальна література продукує форми та освоює теми, які ще не готова опанувати художня [Гинзбург 1977:29-33]. Своєрідність чорнобильського наративу відзначав i М. Павлишин, зауважуючи при цьому, що «епічність», «документальність» та «драматичність» у творах чорнобильської тематики 
відіграють не визначальну, а службову місію в естетичній аргументації твору, $\epsilon$ засобом впливу на когнітивно-емоційну сферу читача [Павлишин 1991:31].

Утім, діяльність людини, скерована на підкорення та перетворення природного середовища, iï бездумне втручання у навколишній світ, яке призводило до порушення гармонії у ньому; руйнівний потенціал атому задовго до появи «чорнобильської бібліотеки» знайшли відображення в творчості Роллана Сейсенбаєва.

Р. Сейсенбаєв - класик сучасної казахстанської літератури: белетрист, драматург, перекладач, видавець, головний редактор журналу зарубіжної літератури «Аманат». Жанровий діапазон письменника складають романи, повісті, оповідання, драматичні твори. Його найвідоміші романи: «Якщо хочеш жити», «Сходи в нікуди», «Трон сатани», «Мертві блукають у пісках» сповнені глибокого драматизму, екзистенційної проблематики, філософських розмірковувань щодо сенсу буття, місії людини, непроминальних цінностей.

Оповідання Р. Сейсенбаєва «День, коли обвалився світ» (1988) автобіографічного характеру. Документальний, публіцистичний та художній виміри у ньому тісно пересновані. Адже йдеться не про стилізацію, не про вірогідну загрозу чи трагічне сприйняття дійсності, а про «автореференцію», художню фіксацію реальних подій, тектонічних зсувів доби; оскарження автором гіркого приділу рідного краю. Центральне місце в оповіданні відведено епізоду вибуху першої водневої бомби поблизу гір Чингістау, на Семипалатинському ядерному полігоні. Семирічним хлопчиком автор став свідком військових випробувань, евакуації жителів 3 рідного аулу до міста Аягуз та обласного Семипалатинська, - літнім мешканцям дозволили разом 3 худобою відійти в гори. Разом із ними залишаються двоє дітей: дівчинка-сирота Кенже, у якої, окрім стареньких дідуся і бабусі, нікого немає, та оповідач. Кенже - його перше дитяче кохання. Позиція автора - безпосереднього учасника нелюдського експерименту - не безстороння. Драма малої батьківщини митця - це і його особиста драма, зіткана 3 нещасть і потрясінь. Відтак, трагедія Степової Країни відтворена з надзвичайною експресією. 
Напередодні припинення наземних випробувань на Семипалатинському полігоні Роллан Сейсенбаєв оповіданням «День, коли обвалився світ» фактично започатковує обговорення екологічних катастроф, пов'язаних із радіоактивним забрудненням. Проте, Семипалатинськ майже ніколи не згадується в усталеному переліку ядерних катаклізмів: Хіросіма і Нагасакі, Чорнобиль, Фукусіма. Так само, як не згадується і той факт, що до чорнобильської біди на пострадянському просторі був досвід радіоактивного ураження, a, отже, відповідно мали б існувати розроблені методи захисту та допомоги потерпілим. Втілення «ядерного катастрофічного дискурсу» в літературі також розпочинається до чорнобильського його варіанту, про який Т. Гундорова зауважує: «Кінец̧ь століття найконцеентрованіме відображає ідеї катастрофізму, а ядерний вибух, посуті, символізує в свідомості людей другой половиниХХ століття кінцеесвітню ідею» [Гундорова 2005:13].

Візії кінця світу наявні й в оповіданні Р. Сейсенбаєва:

«На війну ішли, такого жаху не відчували, - зауважив хтось 3 аксакалів.

- То була війна, а це - кінець світу.

- Значить, правду отой приїжджий хлопець говорив, якого потім міліція заарештувала. [...] Кінецьь світу. 1953 рік. 17 серпня. 6 година 12 хвилин. Все почнеться в Казахстані!» [Сейсенбаєв: Електронний ресурс].

Проте, ще жаскіше відчуття невідворотної загрози передається через діалогічні стосунки та свідомісні вияви персонажів-дітей, насамперед, малої Кенже. Автор наділяє дівча рисами безневинності, безгрішності, а ii нещасливий рід високими моральними чеснотами: «Міŭ дід казав, щзо вони живі лише власною честю. Відбери у них честь, $і$ вони загинуть одразу ж - не стануть, як інші, жити-бути, наче нічого й не сталося». Вказує на неординарність, унікальність дівчинки: «Кенже, у свої шість років розмовляла загадково, дивно, а інколи й дивовижно - фантазї у неї були кольоровими, яскравими. «Буде гарно, буде степ духмяніти, - говорила вона, - квіти багряні так добре пахнуть, $і$ синє-синє небо буде ніжно дивитися на нас, $i$ золоте сонце весело засяє, $і$ у изе золоте дзеркальце можна буде дивитися скільки 
завгодно. Золоте, ласкаве, найрідніше сонечко моє!..» [Сейсенбаєв: Електронний ресурс]. Кенже - вродлива і добра душею: «вона любила все і всіх». Ці характеристики підкреслюють зловісну несправедливість загибелі дитини, яка передбачила власну страшну смерть.

Есхатологічне видиво із силуетом Кенже, котра збожеволівши від страху, біжить назустріч своїй згубі, назавжди закарбується у пам’яті іiі товариша дитинства: «I - тихо похитнулася земля. Мені здалося, щзо вона - вічна колиска, щзо присипляе нас. Але земля раптом здригнулася щзосили, скаженими поштовхами почала бити нас знизу - у ноги, у груди, в обличчя. Ослабнули бабусині обійми. Земля зметнулася, наче ошалілий необ’̈̈жджений кінь. Степ і гори в останній напрузі утримувалися, аби не згинути. Я бачив, визирнувши 3-під кошми - величезний гриб заповнив небо, $i$ вогненні сполохи грали немислимим буйством кольорів. Страх $i$ здивування водночас скували мою душу, такого мені $і$ в найстрашнішому сні привидітися не могло. Стогнали гори, гуркочучи, котилися вниз величезні камені, скрипіли, гнулися дерева, $i$ в пекельні ичі звуки раптом вплівся щуе один - відчайний виск чи плач, щзо аж наче рвав барабанні перетинки. ... Я досі не знаю, як правильно назвати изей звук. Маленька дівчинка в білій сукенці бігла намагаючись уникнути величезних каменів, щзо котилися згори. Я й сам не помітив, як вибрався з-під кошми $i$, випроставшись, остовпіло дивився їй услід. Вогненний гриб важко піднімався, сліпили очі яскраві сполохи, а по землі, щзо гойдалася, утікала невідомо куди маленька дівчинка. Я застиг, як вкопаний, не знаючи, щзо мені вчинити. Її крик рвав мені слух. А може, не було крику? Може, вона беззвучно відкривала рот $i$ бігла не y cmen, а у гори, $i$ навпаки - камені втікали від неї» [Сейсенбаєв: Електронний ресурс].

Катастрофізм є засадничим принципом в оповіданні Р. Сейсенбаєва. У творі знайшли художнє втілення атрибути Апокаліпсису: вода і вогонь. Два Біблійні символи, які мають магічні очищувальні, живодайній водночас руйнівні властивості; $€$ уособленням творення та знищення. Смертоносні вогняні відблиски вибуху, забруднена вода у криницях аулу прирікають його на 
вимирання. Але жителі степу, які стали заручниками чужого безголів’я, на відміну від поінформованих представників влади та високого військового керівництва, не відразу усвідомили невидиму загрозу. Майор медичної служби Жаворонков повідомляє, що «лікарі чекають на прибуття дев’ятьох людей, яких вибух застав саме біля місця випробовування і які стояли та дивилися на все, що відбувалося, навіть не захистившись. За ними будуть наглядати тут днів із десять, а потому відправлять до Семипалатинська, де їх обстежать московські професори». А тоді констатує: «Такі дослідження потрібні для майбутнього». Виявилося, що це місцеві мешканці, саме їх так нагло застав вибух. 3-поміж них i бухгалтер Талгат, який радів, що отримав півтисячі карбованців компенсації на відселення. Він помер одним із перших, на початку 60-х, від раку крові. Антигуманна фраза «наука вимагає жертв» трактується автором як знакова для катастрофічного часу. «Заради науки? Заради майбутнього? Заради землі? Заради людей?...», - риторично запитує він. Благі наміри, які втілюються не благими засобами. Адже приреченими виявляються не лише учасники військового експерименту, але й тутешнє населення, діти, природа, земля. Вибухи на Семипалатинському полігоні стають першопоштовхом нових мутацій, далекосяжних шкідливих наслідків техногенної доби.

Драматизм твору виявляється через бінарні опозиції: «добро-зло», «життя-смерть», «краса-потворність», «надія-песимізм». Через низку вражаючих художніх деталей: посивілу кицьку Руду, яку не впізнає Роллан, переляканих коней, яких відшукали лише наступного дня. I у першу чергу, зрадливу земну твердь, яка втікала з-під ніг: «Земля знову задрижала, тепер ще сильніше, вона билася, як у пропасниці, і серизе моє билося - уверх-униз, унизуверх, $і$ душа завмирала. Я забув про Кенже, я забув про все на світі, я зрозумів - на мене обвалився світ, і зараз я загину під його уламками. Я думав лиме про себе, смерть стояла наді мною із занесеною сокирою, вжик-вжиквжик - $і$ лезо опуститься на мою дитячу шию!» [Сейсенбаєв: Електронний pecypc]. 
Рідний край як об’єкт художнього зображення у письменника постає в різних іпостасях. На початку розповіді природа втілює гармонію і чисту вітальність: «Високі гірські перевали, гірські долини, зелені луки, дерева, ріки, джерела, - ия дивовижна, незаймана краса вражала мене, хлопчика, що вперше потрапив на джайляу, манила своєю таємничістю» [Сейсенбаєв: Електронний ресурс]. Дідизна літератора - особливий топос, наділений сакральністю, яка виявляється через культурні коди. Ця земля народила батирів i поетів, провідників нації - Абая Кунанбаєва, Мухтара Ауезова, Шакаріма Кудайбердієва, а тепер всіяна їх могилами: «Десь отут лежить у колодязі не поховане тіло Шакаріма-хаджі, - сказав Акрам, і всі разом замовкли. [...] дух великого хаджі досі витае у циих міжгір'ях, як тінь нічного барса» [Сейсенбаєв: Електронний ресурс]. Людська пам'ять, символічна реінкарнація, містичне пригадування, включеність минулого у реальне життя породжують тяглість поколінь. Свідченням тому і постійні внутрішні діалоги автора 3 покійним батьком. «Батьку! - вигукнув я. - Батьку, ви живі?! Хіба не вас поховав я на старому казахському кладовищі біля соснового бору, що на крутому березі Іртишу?..», - почувши уві сні рідний далекий голос, чудується син. Р. Сейсенбаєву властиве вільне пересування у часопросторі минулого, сучасного та майбутнього. Дійові особи його прози мертві, живі й ненароджені, a також одухотворена природа, яка зазвичай виступає учасницею подій. В оповіданні відбувається поглиблення персоніфікації та трансформація образу землі, проявлення iї темного лику. Благодатна та життєдайна спершу, вона перетворюється на скалічену, осквернену. сплюндровану, чужу, ворожу, втрачену, мертву.

Рідний Семипалатинськ для автора - центр, у якому акумулюється увесь Казахстан; він - мірило долі країни та народу. Але водночас письменник охоплює поглядом усю територію Великого Степу. Біля гір Чингістау на забрудненому радіацією просторі з'являються на світ хворі діти. У сестри товариша, з яким письменник через 33 роки після вибуху, відвідує могилу Кенже, первісток, народився калікою - без рук. «Потому сестра народила щуе 
двох дітей, але вони прожили недовго, загинули від лейкозу. Вона народила четверту дитину. Проте ией син також калічний: у нього не заростає тім'ячко» [Сейсенбаєв: Електронний ресурс].

Утім, i в інших регіонах батьківщини письменник побачив багато людського горя: «В Джамбулі мені показали жертв хімізаиії - дітей з двома головами, трьома руками та ногами, досі пам'ятаю ці страмні нелюдські обличчя, відчай матерів, напружене мовчання батьків. Я згадав людей з Аралу, щяо гинуть від швидкісного раку стравоходу, згадав біди вугільної Караганди, нафтоносного Мангишлаку, Гур'єва. Уранові копальні Байконуру, мідь та свинець Східного Казахстану - на мапі колись вільного степу зараз навряд чи знайдеш місие, де можна вдихнути чистого повітря, ковтнути чистої води, босоніж пройтися по рідній землі, не боячись опромінитися, отруїтися, заразитися» [Сейсенбаєв: Електронний ресурс].

Покалічені ландшафти у художньому світі Р. Сейсенбаєва - це і частина іншої проблеми, ментальної; адже, природне середовище і соціум нерозривно пов'язані. Розвиток важкої промисловості у 70-80 роках XX століття, екологічні біди Аральського моря, наслідки ядерних катаклізмів на Семипалатинському полігоні призводять до руйнування звичного способу життя казахів, деформації системи їх цінностей, втрати родової пам'яті багатьох поколінь. В контексті вигублення життєвого простору нації, етнокультурної ідентичності народу для письменника генні мутації та занедбання рідної мови - рівновеликі: «А постійне нищення та зневага до казахської мови? Ось іще одна з сонму трагедій, які досі замовчують балакуни та політикани...» [Сейсенбаєв: Електронний ресурс].

В оповіданні P. Сейсенбаєва конструювання текстуального простору відбувається за допомогою контрасту - світла й пітьми, святості й безбожжя. Болісна любов автора до рідної землі виявляється в дуалістичній візії земного раю та юдолі страждань. Він концептуально бачить історичну долю, сучасний стан та перспективи Вітчизни; водночас сповнений передчуттям планетарної ядерної катастрофи. Відтак, хроніка життя душі письменника завершується 
мрією про зцілення Казахстану, категоричним імперативом його порятунку: «Так поверніть же мою батьківщину! - закричав я. - Я хочу, як наказав батько, пройти босоніж по зеленій траві, я хочу напитися води з наших озер, я хочу лежати на чистій та добрій землі $і$ дивитися в чисте, добре небо. Вітчизно, ти чуєш мене?!» [Сейсенбаєв: Електронний ресурс].

У нашому дослідженні значну увагу приділено з'ясуванню основних особливостей поетики оповідання Р. Сейсенбаєва «День, коли обвалився світ», а також співвідношенню художнього світу автора із літературно-естетичними тенденціями творів чорнобильської тематики. Вказано на наявність типологічних аналогій у них. Визначено домінанти катастрофічного дискурсу, якими $\epsilon$, зокрема, пошуки нової образно-художньої мови, жанрова трансформація (з помітним тяжінням до автобіографізму та документалізму). Розглянуто аспекти: катастрофізм як тип художнього сприйняття, людина як об'єкт катастрофи. Окреслено апокаліптичні мотиви і атрибути в оповіданні. Продемонстровано, що апокаліптичні проблеми породжують низку інших особистісних, соціально-психологічних. Зауважено, що екологічні катастрофи, поруйнування звичного життєпростору степовиків змінюють їхню етнокультурну ідентичність, деформують національне світобачення.

\section{БІБЛІОГРАФІЯ}

Алексієвич 1998 - Алексієвич С. Чорнобиль: хроніка майбутнього / С. Алексієвич ; пер. О. Забужко. - К. : Факт, 1998. - 196 с.

Гейзинга : Електронний ресурс - Гейзинга, Йоганн. У затінку завтрашньої днини / Йоганн Гейзинга. - Режим доступу: http://www.gumer.info/bibliotek_Buks/Culture/Heizin/05.php.

Гинзбург 1977 - Гинзбург Л. Я. О психологической прозе / Лидия Яковлевна Гинзбург. - Л. : Художественная литература, 1977. - 448 с.

Гундорова 2005 - Гундорова Т. Післячорнобильська бібліотека : Український літературний постмодернізм / Тамара Гундорова. - К. : Критика, 2005. - 263 c. 
Дзюба 1998 - Дзюба Т. Хутірська концепція П. Куліша / Тетяна Дзюба. Слово і Час. - 1998. - №4/5. - С. 43-46.

Павлишин 1991 - Павлишин М. Чорнобильська тема і проблема жанру / М. Павлишин // Вісн. АМ УРСР. - 1991. - № 4. - С. 30-35.

Сейсенбаєв : Електронний ресурс-Сейсенбаев Р. Тоска по отцу, или День, когда рухнул мир / Р. Сейсенбаев: Рассказы. - Алма-Ата: Жазушы, 1990. 512 с. - Режим доступу: http://profilib.com/chtenie/155455/rollan-seysenbaev-denkogda-rukhnul-mir-12.php.

Харлан 2008 - Харлан О. Моделі катастрофізму в українській та польській прозі міжвоєнного двадцятиліття. автореферат дис. ... д-ра філол. наук : 10.01.05 - порівняльне літературознавство / О. Д. Харлан. - Київ, 2008. $35 \mathrm{c}$. 